\title{
PENGEMBANGAN MODUL FISIKA BERBASIS POTENSI LOKAL "BATIK LUMBUNG DAN TAHU TAMANAN" UNTUK SISWA SMA DI KECAMATAN TAMANAN BONDOWOSO (MATERI SUHU DAN KALOR)
}

\author{
${ }^{1)}$ Putri Utami Wulandari Agustin, ${ }^{1)}$ Sri Wahyuni, ${ }^{1)}$ Rayendra Wahyu Bachtiar \\ ${ }^{1)}$ Program Studi Pendidikan Fisika FKIP Universitas Jember \\ Email: putriutamiwulandariagustin@gmail.com
}

\begin{abstract}
The purpose of this research was to develop and described the validity of Physics Module Based on Local Potential "Batik Lumbung and Tahu Tamanan” for High School Students Tamanan Bondowoso Subdistrict (Material of Temperature and Heat) and described students response toward the module. The design of this research was $4 D$ development. The descriptive percentage was used to analyze the module validity. The average of the module from the expert based on didactic, construction and technical aspect was $94.34 \%$. It was categorized as Very Valid or usable without Revision. The average of the module from the user based on format and language aspect was $93.75 \%$. It was categorized as Very Valid or usable without Revision. The validity of the audience for cognitive aspect was $74.5 \%$ and $73.61 \%$ for psychomotor aspect. The module was Quite Valid or Usable but Needs to be Revised Small. Based on the affective aspect, it was categorized as Very Valid or usable without Revision with the average score $89.65 \%$. The utilization of the Physics module in learning got the positive response from the students with $91.05 \%$ in percentage. Physics module based on local potential was good and appropriate as the alternative for learning material.
\end{abstract}

Keyword: local potential, module, response, validity

\section{PENDAHULUAN}

Kurikulum yang akan diterapkan di sekolah harus mengacu pada UndangUndang Nomor 20 Tahun 2003 pada BAB $\mathrm{X}$ tentang kurikulum, salah satunya pasal 36 ayat 3 butir d, bahwa "Kurikulum disusun sesuai dengan jenjang pendidikan dalam kerangka Negara Kesatuan Republik Indonesia dengan memperhatikan keragaman potensi daerah dan lingkungan". Undang-Undang ini menjelaskan bahwa mengharuskan setiap sekolah untuk menerapkan model pendidikan berbasis keunggulan/potensi lokal yang terdapat pada masing-masing daerah sebagai sarana untuk lebih mengenalkan siswa pada lingkungannya, sehingga memiliki keterampilan yang sesuai dengan potensi lokal yang dimiliki daerahnya (Putri et al. 2014).
Potensi lokal adalah potensi sumber daya spesifik yang dimiliki suatu daerah meliputi potensi sumber daya alam, potensi sumber daya manusia, teknologi, geografis, budaya, dan historis (Mumpuni, 2013; Sarah dan Maryono, 2014). Standar isi yang dikembangkan oleh Badan Standar Nasional Pendidikan (BSNP) (dalam Merintandika et al. 2016) menguraikan mengenai prinsip-prinsip pengembangan dan pelaksanaan kurikulum yang berkaitan dengan potensi daerah. Prinsip-prinsip tersebut diantaranya, berpusat pada potensi, perkembangan, kebutuhan, dan kepentingan peserta didik dan lingkungannya, dan memanfaatkan lingkungan sekitar sebagai sumber belajar. Namun pada penerapannya, masih jarang kurikulum di sekolah yang mengintegrasikan antara materi pembelajaran dengan potensi lokal. 
Fisika merupakan ilmu pengetahuan yang mempelajari gejala-gejala dan kejadian alam (Wahyuningsih et al. 2016). Artinya mata pelajaran Fisika sebagai salah satu bagian dari pendidikan memiliki potensi yang sangat besar untuk dapat diintegrasikan dengan potensi lokal yang terdapat di sekitar lingkungan sekolah.

Kurikulum yang saat ini diimplementasikan oleh pemerintah adalah kurikulum 2013. Karakteristik utama kurikulum 2013 menurut Permendikbud Nomor 69 Tahun 2013 adalah pertama, sesuai dengan Undang-Undang Nomor 20 Tahun 2003 pada BAB X pasal 36 ayat 3 butir d tentang memanfaatkan lingkungan sebagai sumber belajar. Kedua, menjelaskan bahwa pola pembelajaran berpusat pada peserta didik (menjadikan siswa sebagai pusat dalam proses pembelajaran). Oleh karena itu, untuk mengimplementasikan kedua karakteristik tersebut, dibutuhkan sarana yang tepat, salah satunya dengan menyediakan bahan ajar yang mengintegrasikan antara materi pembelajaran Fisika dengan potensi lokal yang terdapat di sekitar lingkungan sekolah sekaligus mampu menjalankan prinsip "student centered" (berpusat pada peserta didik/siswa) yaitu bahan ajar cetak berupa modul.

Bahan ajar dapat didefinisikan sebagai uraian dari seperangkat materi yang disusun secara sistematik baik tertulis maupun tidak tertulis sehingga tercipta lingkungan atau suasana yang memungkinkan siswa untuk belajar (Wahyuni, 2015). Modul merupakan bahan ajar yang disusun secara sistematis dan menarik yang mencakup isi materi, metode, dan evaluasi yang dapat digunakan secara mandiri. Dengan menggunakan modul, siswa dapat belajar secara mandiri tanpa atau dengan bimbingan guru, adanya kontrol terhadap hasil belajar melalui penggunaan standar kompetensi dalam setiap modul yang harus dicapai oleh siswa, dan mereka menjadi lebih bertanggung jawab atas segala tindakannya (Setyowati $e t$ al. 2013). Selain itu, modul merupakan bahan ajar yang disusun sendiri oleh pendidik/guru, maka apabila pembelajaran Fisika menggunakan modul, proses pengintegrasian antara materi Fisika dengan potensi lokal yang terdapat di sekitar lingkungan sekolah berpeluang besar dapat terlaksana.

Hasil wawancara di SMA Negeri Tamanan Bondowoso menunjukkan bahwa sekolah belum menggunakan modul, namun menggunakan buku paket yang sudah ada dipasaran. Sedangkan materi Fisika dalam buku paket yang digunakan tidak memungkinkan untuk membahas kaitannya dengan potensi lokal yang terdapat di sekitar lingkungan sekolah, sehingga kurang familiar bagi siswa. Hal ini menjadi salah satu faktor mata pelajaran Fisika belum dapat dipahami dengan baik oleh siswa dan berakibat terhadap hasil belajarnya yang belum sesuai dengan harapan. Hasil observasi, $70 \%$ siswa menyatakan masih kesulitan memahami materi Fisika dan mengangganya pelajaran yang membosankan.

Menindaklanjuti permasalahan tersebut, maka perlu dikembangkan bahan ajar berupa modul Fisika berbasis potensi lokal. Kecamatan Tamanan, Kabupaten Bondowoso ini terkenal dengan sentra Batik Lumbung dan Tahu Tamanan. Batik Lumbung adalah salah satu produksi batik khas Bondowoso yang berdiri sejak tahun 2012 (Bifadlika dan Russanti, 2016). Tahu Tamanan adalah makanan khas Tamanan yang terbuat dari biji kedelai. Penelitian Hasanah et al. (2016), menunjukkan bahwa hasil belajar siswa menggunakan modul mitigasi bencana berbasis potensi lokal yang terintegrasi dalam pelajaran IPA di SMP termasuk dalam kategori tinggi. Penelitian Novana et al. (2014), menunjukkan bahwa hasil belajar menggunakan modul inkuiri terbimbing berbasis potensi lokal pada materi Tumbuhan Lumut dan Tumbuhan Paku lebih baik dibandingkan dengan hasil belajar dari pembelajaran konvensional.

Berdasarkan uraian tentang permasalahan di SMA Negeri Tamanan 
Bondowoso, maka penelitian ini mengembangkan Modul Fisika Berbasis Potensi Lokal "Batik Lumbung dan Tahu Tamanan" untuk Siswa SMA di Kecamatan Tamanan Bondowoso (Materi Suhu dan Kalor). Modul Fisika yang disusun dengan mengintegrasikan antara materi "Suhu dan Kalor" dengan potensi lokal "Batik Lumbung dan Tahu Tamanan”. Modul Fisika ini juga mampu membantu membangun pengetahuan siswa serta mudah dibawa kemana-mana. Oleh karena itu, penelitian ini bertujuan untuk mengembangkan dan mendeskripsikan validitas modul serta mendeskripsikan respon siswa terhadap modul yang dikembangkan.

\section{METODE}

Penelitian ini adalah penelitian dan pengembangan $(R \& D)$ menggunakan desain pengembangan 4-D oleh Thiagarajan et al. (1974). Penelitian ini dilaksanakan pada bulan Maret-April 2017 di SMA Negeri Tamanan Bondowoso. Subjek penelitian ini adalah siswa kelas XIPA 1 berjumlah 27 orang yang diambil satu kelas secara acak. Data yang diperoleh dianalisis dengan deskriptif persentase.

Tahap Pendefinisian (Define) yaitu meliputi analisis ujung depan, analisis siswa, analisis tugas, analisis konsep, dan perumusan tujuan pembelajaran yang dapat dijadikan dasar pembuatan modul Fisika berbasis potensi lokal.

Tahap Perancangan (Design) yaitu meliputi penyusunan tes hasil belajar siswa aspek kognitif berupa posttest yang terintegrasi dengan potensi lokal di sekitar lingkungan SMA Negeri Tamanan Bondowoso, pemilihan media, pemilihan format, dan rancangan awal.

Tahap Pengembangan (Develop) yaitu meliputi validasi oleh ahli dan pengguna, serta uji pengembangan (validasi audience/siswa dan respon siswa). Validasi ahli dilakukan oleh tiga dosen Program Studi Pendidikan Fisika FKIP Universitas Jember. Validasi pengguna dilakukan oleh satu guru bidang studi Fisika SMA Negeri Tamanan Bondowoso. Validasi audience meliputi aspek kognitf yang diukur setelah pembelajaran menggunakan modul, aspek afektif dan psikomotorik diukur selama pembelajaran.

Teknik analisis data untuk validitas ahli, pengguna, dan audience dihitung menggunakan persamaan berikut:

$$
V=\frac{T_{s e}}{T_{s h}} x 100 \%
$$

$T_{s e}=$ total skor empiris yang diperoleh

$T_{s h}=$ total skor maksimal

(Akbar, 2013: 83).

Tabel 1. Kriteria Validitas

\begin{tabular}{ll}
\hline Kriteria Validitas & \multicolumn{2}{c}{ Tingkat Validitas } \\
\hline $85,01 \%-100,00 \%$ & $\begin{array}{l}\text { Sangat valid, atau } \\
\text { dapat digunakan tanpa } \\
\text { revisi }\end{array}$ \\
\hline $70,01 \%-85,00 \%$ & $\begin{array}{l}\text { Cukup valid, atau } \\
\text { dapat digunakan } \\
\text { namun perlu direvisi } \\
\text { kecil }\end{array}$ \\
\hline $50,01 \%-70,00 \%$ & $\begin{array}{l}\text { Kurang valid, } \\
\text { disarankan tidak } \\
\text { dipergunakan karena } \\
\text { perlu revisi besar }\end{array}$ \\
\hline $01,00 \%-50,00 \%$ & $\begin{array}{l}\text { Tidak valid, atau tidak } \\
\text { boleh dipergunakan }\end{array}$ \\
\hline
\end{tabular}

(Akbar, 2013: 41).

Respon siswa dilakukan dengan membagikan angket pada siswa setelah pembelajaran menggunakan modul. Teknik analisis data untuk respon siswa dihitung menggunakan persamaan berikut:

$$
N P R=\frac{A}{B} x 100 \%
$$

$\mathrm{NPR}=$ nilai persentase respon siswa $\mathrm{A}=$ jumlah siswa yang memilih $\mathrm{B}=$ jumlah siswa

(Purwanto, 2012: 102).

Tabel 2. Kriteria Respon Siswa

\begin{tabular}{cc}
\hline Kriteria & Interval \\
\hline Sangat Positif & $81-100 \%$ \\
\hline Positif & $61-80 \%$ \\
\hline Cukup Positif & $41-60 \%$ \\
\hline Kurang Positif & $21-40 \%$ \\
\hline Tidak Positif & $<21 \%$ \\
\hline
\end{tabular}

(Arikunto, 2010: 35). 
Tahap Penyebaran (Disseminate) yaitu oleh peneliti hanya dilakukan dengan sosialisasi keberadaan Modul Fisika Berbasis Potensi Lokal "Batik Lumbung dan Tahu Tamanan" untuk Siswa SMA di Kecamatan Tamanan Bondowoso (Materi Suhu dan Kalor) di kelas lain (sesuai Isworini et al. 2015) yaitu kelas X-IPA 2 dan X-IPA 3. Hal ini dikarenakan biaya dan waktu yang digunakan dalam penelitian masih terbatas.

\section{HASIL DAN PEMBAHASAN}

Modul Fisika Berbasis Potensi Lokal "Batik Lumbung dan Tahu Tamanan" untuk Siswa SMA di Kecamatan Tamanan Bondowoso (Materi Suhu dan Kalor) ini terdiri dari sampul; kata pengantar; penggunaan modul; abstrak; peta wilayah potensi lokal; daftar isi; peta konsep; info potensi lokal; standar isi dan lembar keterangan kegiatan belajar; materi; analisis pertanyaan; contoh soal dan pembahasan; kegiatan eksperimen; latihan soal; rangkuman; tes formatif dan kunci jawaban; tes kompetensi; daftar pustaka; dan tentang penulis.

Validitas ahli dan pengguna terhadap modul yang dikembangkan berupa data kuantitatif dan data kualitatif.

Tabel 3. Data Kuantitatif Validitas Ahli dan Pengguna

\begin{tabular}{ccc}
\hline Aspek & Validitas & Tingkat Validitas \\
\hline Ahli & & \\
\hline $\begin{array}{c}\text { Didaktik } \\
\text { Konstruksi } \\
\text { Teknis }\end{array}$ & $94,34 \%$ & $\begin{array}{c}\text { Sangat Valid, atau } \\
\text { dapat digunakan } \\
\text { tanpa revisi }\end{array}$ \\
\hline Pengguna & & \\
\hline $\begin{array}{c}\text { Format } \\
\text { Bahasa }\end{array}$ & $93,75 \%$ & $\begin{array}{c}\text { Sangat Valid, atau } \\
\text { dapat digunakan } \\
\text { tanpa revisi }\end{array}$ \\
\hline
\end{tabular}

Tabel 3 validitas ahli menjelaskan bahwa modul Fisika berbasis potensi lokal yang dikembangkan sudah memenuhi kelayakan teoritis (aspek didaktik, konstruksi, dan teknis). Pertama, artinya isi modul sudah mengacu pada kurikulum
2013 dan mengandung unsur untuk mendorong rasa ingin tahu siswa. Aisyi et al. (2013) menyatakan bahwa dalam menyusun sumber belajar perlu memperhatikan kurikulum, sesuai dengan persyaratan untuk penyusunan sumber belajar yang baik. Masita et al. (2013) menyatakan bahwa pada syarat didaktik, sarana yang dikembangkan lebih menekankan pada proses untuk menemukan konsep-konsep sebagai penunjuk jalan bagi siswa untuk mencari tahu.

Kedua, artinya isi modul bersifat komunikatif. Darmiyati Zuchdi (dalam Akbar, 2013: 35) menjelaskan komunikatif artinya isi buku mudah dicerna pembaca, sistematis, jelas, dan tidak mengandung kesalahan bahasa. Bahan ajar disusun untuk memudahkan pencapaian tujuan pembelajaran, maka bahan ajar harus disusun secara sistematis agar lebih mudah untuk digunakan oleh siswa dan guru dalam proses pembelajaran (Hardini et al. 2013; Leksono et al. 2015). Ketiga, artinya penyajian, gambar, tulisan, dan penampilan modul dikategorikan sangat baik dan menarik. Majid (2011: 176) menyatakan bahwa buku yang baik adalah buku yang disajikan secara menarik dilengkapi gambar dan keterangan-keterangannya. Depdiknas (2008) menjelaskan bahwa penyusunan bahan ajar cetak perlu memperhatikan susunan tampilan (urutan yang mudah dan judul yang singkat), kemudian kemudahan dibaca yang artinya menyangkut keramahan terhadap mata (huruf yang digunakan tidak terlalu kecil dan enak dibaca).

Data kualitatif validitas ahli dan pengguna berupa komentar dan saran terhadap modul Fisika berbasis potensi lokal yang dikembangkan menunjukkan bahwa beberapa hal perlu direvisi, yaitu tata tulis, penampilan, bahasa, kedalaman materi, dan kebenaran konsep.

Tabel 3 validitas pengguna menjelaskan bahwa modul Fisika berbasis potensi lokal yang dikembangkan sudah dapat digunakan di kelas. Artinya, format 
dan bahasa pada modul tersebut sudah memenuhi kondisi sekolah dan karakteristik siswa. Depdiknas (2008) menjelaskan bahwa bahan ajar yang dikembangkan, harus disesuaikan dengan karakteristik sasaran.

Modul Fisika berbasis potensi lokal yang dikembangkan sudah dinyatakan layak, selanjutnya dapat dilakukan tahap uji pengembangan. Melalui tahap ini, peneliti dapat memperoleh masukan langsung meliputi validitas audience (hasil belajar siswa) dan hasil respon siswa. Menurut Tyas et al. (2015), hasil belajar siswa adalah hasil yang didapatkan siswa setelah melakukan kegiatan pembelajaran yang mencakup akumulasi ranah kognitif, afektif, dan psikomotorik.

Tabel 4. Data Validitas Audience

\begin{tabular}{ccc}
\hline Aspek & Validitas & $\begin{array}{c}\text { Tingkat } \\
\text { Validitas }\end{array}$ \\
\hline Kognitif & $74,5 \%$ & $\begin{array}{c}\text { Cukup valid, } \\
\text { atau dapat } \\
\text { digunakan } \\
\text { namun perlu } \\
\text { direvisi kecil }\end{array}$ \\
\hline
\end{tabular}

\section{Afektif}

\begin{tabular}{|c|c|c|}
\hline $\begin{array}{l}\text { Keingintahuan } \\
\text { Tanggung } \\
\text { Jawab } \\
\text { Keberanian } \\
\text { Berpendapat }\end{array}$ & $89,65 \%$ & $\begin{array}{c}\text { Sangat valid, } \\
\text { atau dapat } \\
\text { digunakan } \\
\text { tanpa revisi }\end{array}$ \\
\hline \multicolumn{3}{|l|}{ Psikomotorik } \\
\hline $\begin{array}{l}\text { Melakukan } \\
\text { pengamatan } \\
\text { Menganalisis } \\
\text { pertanyaan } \\
\text { Menyimpulkan } \\
\text { percobaan }\end{array}$ & $73,61 \%$ & $\begin{array}{c}\text { Cukup valid, } \\
\text { atau dapat } \\
\text { digunakan } \\
\text { namun perlu } \\
\text { direvisi kecil }\end{array}$ \\
\hline
\end{tabular}

Validitas audience (kognitif) pada Tabel 4 menjelaskan bahwa kemampuan mayoritas siswa dalam kategori cukup baik, sehingga masih dapat dikatakan memenuhi tingkat keefektifan penguasaan isi modul, serta sejalan dengan penelitian sebelumnya yang juga menghasilkan hasil positif yaitu menurut Novana et al. (2014), bahwa hasil belajar siswa menggunakan modul inkuiri terbimbing berbasis potensi lokal sebesar $77 \%$. Diantara 27 siswa kelas X-IPA 1, ada 5 siswa yang belum mencapai $\mathrm{KKM}=73$. Hal ini menjelaskan bahwa proses-proses kognitif pada kelima siswa masih belum seluruhnya tercapai. Darmawan dan Sujoko (2013) menjelaskan bahwa proses-proses kognitif meliputi kategori mengetahui; memahami; menerapkan; menganalisis; mengevaluasi; dan menciptakan.

Validitas audience (afektif) pada Tabel 4 menjelaskan bahwa minat belajar siswa menggunakan modul Fisika berbasis potensi lokal yang dikembangkan sangat tinggi. Ambarini et al. (2013) menjelaskan bahwa minat belajar adalah kecenderungan hati yang ditandai dengan adanya perhatian, keingintahuan, dan kebutuhan siswa dalam pembelajaran. Yusuf dan Hamzah (2016), menjelaskan bahwa minat harus dipandang sebagai sesuatu yang sadar. Pencapaian validitas audience (afektif) tertinggi yaitu aspek tanggung jawab siswa dalam pembelajaran menggunakan modul Fisika berbasis potensi lokal yang dikembangkan. Sejalan dengan penelitian Sarah dan Maryono (2014), bahwa pembelajaran menggunakan perangkat pembelajaran berbasis potensi lokal ternyata efektif meningkatkan aspek tanggung jawab siswa dalam belajar.

Validitas audience (psikomotorik) pada Tabel 4 menjelaskan bahwa keterampilan siswa dalam kerja ilmiah berdasarkan panduan modul Fisika berbasis potensi lokal yang dikembangkan berada pada kategori cukup baik. Sugiyanto et al. (2015) menjelaskan bahwa ranah keterampilan yang diukur meliputi kegiatan praktikum. Namun, keseluruhan siswa belum mencapai skor maksimum $=4$ dalam dua kali pertemuan menggunakan modul tersebut. Sejalan dengan penelitian Putri et al. (2014), bahwa pembelajaran menggunakan model PBL berbasis potensi lokal menunjukkan aspek tertinggi adalah menggunakan bukti ilmiah (eksperimen, menganalisis pertanyaan, dan membuat kesimpulan), serta aspek terendah adalah mengidentifikasi isu ilmiah (hipotesis). 
Tabel 5. Data Respon Siswa

\begin{tabular}{ccc}
\hline Indikator & NPR & Kriteria Respon \\
\hline Senang & $98,15 \%$ & Sangat Positif \\
\hline Paham & $98,15 \%$ & Sangat Positif \\
\hline Mudah & $50 \%$ & Cukup Positif \\
\hline Bagus & $100 \%$ & Sangat Positif \\
\hline Menarik & $100 \%$ & Sangat Positif \\
\hline Berminat & $100 \%$ & Sangat Positif \\
\hline $\begin{array}{c}\text { Rata- } \\
\text { rata }\end{array}$ & $\mathbf{9 1 , 0 5 \%}$ & Sangat Positif \\
\hline
\end{tabular}

Tabel 5 menjelaskan bahwa siswa merespon sangat positif terhadap modul Fisika berbasis potensi lokal yang dikembangkan yaitu pada aspek dengan indikator senang, paham, bagus, menarik, serta minat. Sejalan dengan validitas ahli dan pengguna serta sejalan dengan validitas audience (afektif). Selain itu, pencapaian ini juga sejalan dengan penelitian menurut Noviar dan Sulistiyawati (2014), bahwa respon siswa pada aspek minat dan penyajian dalam belajar menggunakan ensiklopedia IPA berbasis potensi lokal menghasilkan persentase tinggi.

Aspek dengan indikator mudah hanya mencapai 50\%. Hal ini karena sebanyak 21 siswa berpendapat bahwa materi yang disajikan mudah untuk dipahami dan sulit mengerjakan latihan soal serta Tes Formatif. Artinya, kemampuan siswa dalam mengaitkan antara konsep Fisika dengan persamaan matematis masih belum terlatih dengan cukup baik, dikarenakan sebelumnya siswa terbiasa dengan penyajian materi Fisika yang kurang familiar, sehingga soal Fisika cenderung dianggap "Sulit" (sesuai hasil observasi di SMA Negeri Tamanan Bondowoso). Namun, validitas audience (kognitif) sudah mencapai validitas "Cukup Valid", sehingga kemampuan siswa dalam mengaitkan antara konsep Fisika dengan persamaan matematis sudah terlatih dengan cukup baik setelah terbiasa mengerjakan latihan soal dan Tes Formatif berbasis potensi lokal yang terdapat di sekitar lingkungan sekolah.
Kendala pada penelitian pengembangan ini adalah masih terdapat beberapa siswa yang bercanda selama melakukan pengamatan (saat praktikum). Solusinya adalah memperingati sekaligus melakukan tanya jawab untuk menguji kefokusannya.

\section{SIMPULAN DAN SARAN}

Berdasarkan hasil penelitian dan pembahasan pengembangan Modul Fisika Berbasis Potensi Lokal "Batik Lumbung dan Tahu Tamanan" untuk Siswa SMA di Kecamatan Tamanan Bondowoso (Materi Suhu dan Kalor), maka dapat disimpulkan bahwa validitas ahli dan pengguna sudah memenuhi kelayakan teoritis dan dapat digunakan di kelas. Validitas audience terhadap modul tersebut juga sudah memenuhi tingkat keefektifan mencapai tujuan pembelajaran, menghasilkan minat belajar siswa yang sangat tinggi, dan keterampilan siswa dalam kerja ilmiah berada pada kategori cukup baik. Respon siswa rata-rata menunjukkan respon "Sangat Positif".

Berdasarkan penelitian dan pengembangan yang dilakukan, saran yang dapat diberikan adalah penyajian materi yang familiar bagi siswa sangat diperlukan untuk menghindari kesulitan siswa, terutama dalam mengaitkan antara konsep Fisika dengan persamaan matematis. Bimbingan selama kegiatan praktikum dengan modul sangat diperlukan untuk menghindari ketidakfokusan siswa. Modul Fisika berbasis potensi lokal ini perlu lebih banyak diuji cobakan pada kelas dan sekolah lain untuk mendeskripsikan validitas modul pada tempat yang berbeda.

\section{DAFTAR PUSTAKA}

Aisyi, F. K., S. Elvyanti, T. Gunawan, dan E. Mulyana. 2013. Pengembangan Bahan Ajar TIK SMP Mengacu pada Pembelajaran Berbasis Proyek. Invotec. IX(2): 117-128. 
Akbar, S. 2013. Instrumen Perangkat Pembelajaran. Bandung: PT Remaja Rosdakarya.

Ambarini, N., A. Rosyidi, dan J. Ariyanto. 2013. Penerapan Pembelajaran Aktif Card Sort Disertai Mind Mapping untuk Meningkatkan Minat Belajar Siswa dalam Pembelajaran Biologi Siswa Kelas VII-E SMP Negeri 5 Surakarta. Bio-Pedagogi. 2(1): 77 87.

Arikunto, S. 2010. Evaluasi Program Pendidikan. Jakarta: Bumi Aksara.

Bifadlika, G. dan I. Russanti. 2016. Pengembangan Motif Batik Bondowoso di Pengrajin "Batik Lumbung". Jurnal Tata Busana. 5(1): 10-18.

Darmawan, I. P. A. dan E. Sujoko. 2013. Revisi Taksonomi Pembelajaran Benyamin S. Bloom. Satya Widya. 29(1): 30-39.

Depdiknas. 2008. Panduan Pengembangan Bahan Ajar. Jakarta: Direktorat Jenderal Manajemen Pendidikan Dasar dan Menengah.

Hardini, R. R., Pujayanto, dan E. Y. Ekawati. 2013. Pengembangan Bahan Ajar IPA Terpadu Berbasis SalingTemas untuk SMP Kelas VII dengan Tema Ekosistem Air Tawar. Jurnal Materi dan Pembelajaran Fisika. 3(1): 9-13.

Hasanah, I., S. Wahyuni, dan R. W. Bachtiar. 2016. Pengembangan Modul Mitigasi Bencana Berbasis Potensi Lokal yang Terintegrasi dalam Pelajaran IPA di SMP. Jurnal Pembelajaran Fisika. 5(3): 226-234.

Isworini, W. Sunarmo, dan S. Saputro. 2015. Pengembangan Modul Pembelajaran Hidrolisis Garam
Berbasis Model Inkuiri Terbimbing (Guidedinquiry) untuk Siswa Madrasah Aliyah Kelas XI. Jurnal Inkuiri. 4(3): 9-20.

Leksono, S. M., A. Syachruroji, dan P. Marianingsih. 2015. Pengembangan Bahan Ajar Biologi Konservasi Berbasis Etnopedagogi. Jurnal Kependidikan. 45(2): 168-183.

Majid, A. 2011. Perencanaan Pembelajaran: Mengembangkan Standar Kompetensi Guru. Bandung: PT Remaja Rosdakarya.

Merintandika, B. A., Yuliani, dan A. N. M. Fauziah. 2016. Kelayakan Teoritis LKS Berbasis Inkuiri Terbimbing Terintegrasi Potensi Lokal Tambak Garam pada Materi Pemisahan Campuran untuk Melatihkan Keterampilan Proses Sains. Jurnal Pendidikan Sains. 4(2): 1-6.

Masita, N. P., E. Susantini, dan M. Thamrin H. 2013. Kelayakan Teoritis Lembar Penilaian Pemahaman Diri Berbasis Metakognitif pada Materi Genetika. BioEdu. 2(3): 286-289.

Mumpuni, K. E. 2013. Potensi Pendidikan Keunggulan Lokal Berbasis Karakter dalam Pembelajaran Biologi di Indonesia. Prosiding Seminar Nasional X Pendidikan Biologi FKIP UNS. 10(2). Universitas Negeri Sebelas Maret: 1-7.

Novana, T., Sajidan, dan Maridi. 2014. Pengembangan Modul Inkuiri Terbimbing Berbasis Potensi Lokal pada Materi Tumbuhan Lumut (Bryophyta) dan Tumbuhan Paku (Pteridophyta). Jurnal Inkuiri. 3(2): 108-122.

Noviar, D. dan Sulistiyawati. 2014. Pengembangan Ensiklopedi IPA Terpadu Berbasis Potensi Lokal 
sebagai Bahan Ajar Mandiri bagi Siswa SD/MI. Prosiding Seminar Nasional X Pendidikan Biologi FKIP UNS. 11(1). Universitas Negeri Sebelas Maret: 1060-1068.

Permendikbud Nomor 69 Tahun 2013. Kerangka Dasar dan Struktur Kurikulum Sekolah Menengah Atas/Madrasah Aliyah. Jakarta.

Purwanto, N. M. 2012. Psikologi Pendidikan. Bandung: PT Remaja Rosdakarya.

Putri, A., Suciati, dan M. Ramli. 2014. Pengaruh Model Problem Based Learning Berbasis Potensi Lokal pada Pembelajaran Biologi terhadap Kemampuan Literasi Sains Siswa Kelas X SMA Negeri 1 Cepogo. BioPedagogi. 3(2): 81-94.

Sarah, S. dan Maryono. 2014. Keefektivan Pembelajaran Berbasis Potensi Lokal dalam Pembelajaran Fisika SMA dalam Meningkatkan Living Values Siswa. Jurnal Pendidikan Sains Universitas Muhammadiyah Semarang. 2(1): 36-42.

Setyowati, R., Parmin, dan A. Widiyatmoko. 2013. Pengembangan Modul IPA Berkarakter Peduli Lingkungan Tema Polusi sebagai Bahan Ajar Siswa SMK N 11 Semarang. Unnes Science Education Journal. 2(2): 245-253.

Sugiyanto, F. N., S. Ridlo, dan Sumadi. 2015. Penggunaan Penilaian Autentik dalam Pembelajaran Biologi dengan Inkuiri Terbimbing dan Pengaruhnya terhadap Hasil Belajar Peserta Didik. Unnes Journal of Biology Education. 4(3): 304-310.
Thiagarajan, S., D. S. Semmel, dan M. I. Semmel. 1974. Instructional Development for Training Teacher of Exceptional Children A Sourcebook. Bloomington: Indiana University.

Tyas, M. W., S. Wahyuni, dan Yushardi. 2015. Pengembangan Bahan Ajar IPA Berupa Komik Edukasi pada Pokok Bahasan Objek IPA dan Pengamatannya di SMP. Jurnal Pembelajaran Fisika. 4(1): 32-37.

Undang-Undang Nomor 20 Tahun 2003. Sistem Pendidikan Nasional. 8 Juli 2003. Lembaran Negara Republik Indonesia Tahun 2003 Nomor 4301. Jakarta.

Wahyuni, S. 2015. Pengembangan Bahan Ajar IPA untuk Meningkatkan Kemampuan Berpikir Kritis Siswa SMP. Prosiding Seminar Nasional Fisika dan Pendidikan Fisika. 6(1). Universitas Jember: 300-305.

Wahyuningsih, R., S. Wahyuni, dan A. D. Lesmono. 2016. Pengembangan Instrumen Self Assessment Berbasis Web untuk Menilai Sikap Ilmiah pada Pembelajaran Fisika di SMA. Jurnal Pembelajaran Fisika. 4(4): 338-343.

Yusuf, A. A. dan A. Hamzah. 2016. Pengaruh Kepercayaan Diri dan Semangat Kewirausahaan terhadap Minat menjadi Wirausaha. AlAmwal. 8(2): 481-490. 